\title{
VEIKSNIAI, LEMIANTYS LKKA STUDENTŲ MOTYVACIJĄ MOKYTIS UŽSIENIO KALBŲ
}

\author{
Aurelija Kuzmienė, Irena Čikotienė, Kęstutis Kardelis \\ Lietuvos kūno kultūros akademija, Kaunas, Lietuva
}

Aurelija Kuzmienė. Socialinių mokslų (edukologijos) magistrè. Lietuvos kūno kultūros akademijos Mokslo skyriaus specialistė. Mokslinių tyrimų kryptis - mokymosi motyvacija.

Irena Čikotienè. Socialinių mokslų (edukologijos) magistrè. Lietuvos kūno kultūros akademijos Kalbų katedros lektorè. Mokslinių tyrimų kryptis - mokymosi aukštojoje mokykloje motyvacija.

\section{SANTRAUKA}

Straipsnyje aprašomas tyrimas, kurio tikslas — atskleisti LKKA studentu motyvacijos mokytis užsienio kalbu raiška ir įvertinti ja lemiančius veiksnius. Juo bandoma patikrinti prielaida, kad studentu motyvacija mokytis užsienio kalbu yra susijusi su ju psichosocialine sveikata ir priklauso nuo pasirinktos studiju krypties. Taikant apklausos raštu metoda, apklausti 225 Sporto edukologijos, Sporto technologiju ir turizmo bei Sporto biomedicinos fakultetu pirmo ir antro kursu studentai. Tyrimo duomenys leidžia formuluoti išvada, bylojančiq apie tai, kad sqsaja egzistuoja tarp studentu motyvacijos mokytis užsienio kalbu ir ju savigarbos, tarpusavio santykiu su déstytojais ir studiju krypties: studentai, kuriu motyvacija mokytis užsienio kalbu yra aukštesnè, yra didesnès savigarbos, labiau pabrėžia santykiu su destytojais svarbq ir pasirinkę studijas Sporto biomedicinos fakultete.

Raktažodžiai: studentu motyvacija, užsienio kalbos, psichosocialinè sveikata.

\section{IVADAS}

$\mathrm{N}$

uolatiniai visuomenès gyvenimo pokyčiai, kuriuos diktuoja globalizacijos iššūkiai, apima visas žmogaus veiklos sritis, tarp jų ir studijas aukštojoje mokykloje. Pokyčiai aukštojo mokslo sistemoje ypač akcentuoja aukštus akademinius standartus, skatina studentus būti atsakingais už savo išsilavinimą, profesini pasirengimą. Šiuo pasirengimo etapu neabejotinai išauga užsienio kalbų mokèjimo svarba, kaip būtina sąlyga ne tik adaptuotis profesinejje veikloje, bet ir integruotis i Europos bei pasaulio šalių bendriją.

Suprantama, kad studentų užsienio kalbų mokymosi sèkmę lemia ne tik aukštosios mokyklos ugdymo(si) technologijos bei edukacinè aplinka, bet ir ju pačiu pastangos, kurias daugiausia lemia motyvacija mokytis. Tačiau tai tik viena klausimo dalis. Kur kas svarbiau įvertinti veiksnius, galinčius daryti itaką studentų motyvacijai mokytis užsienio kalbu, nes motyvuotas poreikis plètoti bei gilinti 
užsienio kalbu žinias, noras imtis atsakomybės už mokymąsi, gebèjimas mokantis pasinaudoti nauju informaciniu ir telekomunikaciniu technologiju teikiamomis galimybemis - visa tai tampa būtinybe norint, kad modernios visuomenès narys neatsidurtų sparčiai kintančios visuomenès šalikelèje (Dereškevičius, 2000). Tad atsiranda paskata domètis tais veiksniais, kurie galètų lemti studentų motyvaciją mokytis užsienio kalbų.

Studentų motyvacijos mokytis užsienio kalbų problemos nèra naujos. Jos plačiai aptartos ir Lietuvos (Balžakienè, 1998; Brunevičiūtè, 2003; Šliogerienè, 2004; Vaznonienè, Danilevičienè, 2004), ir užsienio (Arends, 1994; Gage, Berliner, 1994; Kohohen, 1994; Gardner, 1995) autoriu darbuose. Juose motyvacija buvo tiriama bandant sieti ją su studentų saviraiškos formomis: savęs ir mokymosi proceso pažinimu, savarankiškumu ir savęs skatinimu. Mažiau ieškota motyvacijos mokytis užsienio kalbų sąsaju su psichosocialine sveikata, studijų kryptimi. Pirmuoju atveju tokios sąsajos paieška grindžiama tuo, kad asmens socializacijos procese dèl skirtingos socialinès aplinkos ir paveldèto kryptingumo moty vacijai mokytis gali daryti įtaką ivvairūs sveikatos veiksniai, tarp jų ir aplinkos nulemti psichosocialiniai. Tokios sasajos buvimo prielaidas kelia ir kiti tyrejai (Чаркова, 2004). Be to, tiriant moksleivius, atskleista jų mokymosi motyvacijos sąsaja su tokiais psichosocialinès sveikatos rodikliais kaip savigarba ir socialinè integracija (Leipute, Kardelis, 2002). Antruoju atveju, esant galimybei laisvai rinktis profesiją, labai padideja individualios kompetencijos ir asmeninès atsakomybès reikšmė (Petrauskaitè, 1995), nes nuo to, kaip būsimasis specialistas yra ịvaldęs užsienio kalbų mokejjimo igūdžius, labai priklausys jo komunikacinè kompetencija ir galimybè sėkmingai dirbti Europos Sajungos šalyse. Kita vertus, profesijos prestižas visuomeneje taip pat gali lemti motyvaciją mokytis užsienio kalbų. Tokių sąsajų atskleidimas leistų pamąstyti apie kai kurias pataisas organizuojant užsienio kalbu studijas aukštojoje mokykloje.

Išsakyti teiginiai, grindžiantys sumanyto tyrimo aktualumą, leido formuluoti toki problemini klausimą: ar yra ryšys tarp studentu motyvacijos mokytis užsienio kalbu ir ju pasirinktos studiju krypties bei psichosocialines sveikatos rodikliu? Formuluodami ši problemini klausimą, kèleme dvi hipotezes:

H1: studentų motyvacija mokytis užsienio kalbu susijusi su jų psichosocialine sveikata, t. y. tie studentai, kuriu psichosocialinès sveikatos rodikliai yra aukštesni, labiau motyvuoti mokytis užsienio kalbų.

H2: studentų motyvaciją mokytis užsienio kalbų prognozuoja pasirinkta studijų kryptis, t. y. studentai, pasirinkę studijas Sporto biomedicinos fakultete, lyginant su kitu fakultetų studentais, išsiskiria aukštesne motyvacija mokytis užsienio kalbų.

Tyrimo objektas - veiksniai, lemiantys studentu motyvaciją mokytis užsienio kalbų. Priklausomais tyrimo kintamaisiais pasirinkome mokymosi motyvaciją, o nepriklausomais studiju krypti, psichosocialinès sveikatos rodiklius: santykius su desstytojais ir savigarbą. Pastaraji psichosocialinès sveikatos komponentą pasirinkome dèl to, kad tiriant moksleivius šio komponento sąsaja su mokymosi motyvacija buvo labai ryški (Leipute, Kardelis, 2002). Kalbamuoju atveju psichosocialinė sveikata suprantama kaip socialinių, psichologinių, ekonominių ir kitokių veiksnių, darančių itaką žmogaus gyvenimui, visuma. Jai būdingos tokios psichosocialiai sveiko žmogaus charakteristikos kaip gera savijauta, savikontrolè, mokejimas tramdyti savo jausmus, atlikti veiklą emociškai nepalankiomis aplinkybèmis (Rebecca, Lorraine, 1998). Kitais žodžiais tariant, tai asmenybès emocinio ir socialinio brandumo rodiklis.

Socialiniai demografiniai tyrimo kintamieji lytis, tèvų išsilavinimas, savo materialinès padèties suvokimas, stojimo i akademiją motyvai ir kt. - taip pat buvo ivvardyti kaip nepriklausomi kintamieji, galintys daryti itaką motyvacijai mokytis užsienio kalbų, tačiau tokių sąsaju neprognozavome.

Tyrimo tikslas - atskleisti LKKA studentu motyvacijos mokytis užsienio kalbų raišką ir îvertinti ją lemiančius veiksnius.

\section{TYRIMO METODIKA}

Tiriamieji. Tyrimo metu buvo suformuota atsitiktinè nepriklausoma imtis, kurią sudare 225 Sporto edukologijos, Sporto technologiju ir turizmo bei Sporto biomedicinos fakultetu pirmo ir antro kurso studentai (110 vaikinu ir 115 merginu). Jie visi mokèsi studiju programos dalyko - anglų kalbos.

Tyrimo metodai. Taikytas apklausos raštu metodas. Klausimyno turini sudare 29 klausimai 
ir teiginiai, kuriais aiškintasi studentų motyvacija mokytis užsienio kalbų, stojimo i akademija motyvai, santykiai su dèstytojais, požiūris i žmogaus asmenines savybes, kurios, jų nuomone, gali būti svarbios mokantis užsienio kalbų, asmeninès pastangos, sportinè veikla, socialiniai demografiniai kintamieji ir kt. Savigarbai įvertinti taikyta Rozenbergo savęs vertinimo skale (Fisher, Corcoran, 1987).

Tyrimo procedūros. Studentu apklausa vyko 2005 metu pavasario semestre. Vykdant apklausą buvo vadovaujamasi geranoriškumo, etiniais ir teisiniais principais. Visi tyrimo dalyviai informuoti apie tyrimo tikslą, duomenų anonimiškumą ir supažindinti su klausimyno pildymo instrukcija. Taip pat buvo pabrèžiama, kad dalyvauti tyrime nèra privaloma, tačiau nè vienas studentas neatsisakè tai daryti. Klausimyno užpildymo procedūra buvo vykdoma užsièmimų metu, dalyvaujant vienam iš tyrèjų. Studentams užpildžius klausimynus, tuoj pat jie buvo surenkami. Laiko atsakymams skiriama tiek, kiek reikejjo tyrimo dalyviams, tačiau klausimynui užpildyti pakako 25-30 min. Tiriamujų paprašyta atsakyti i pateiktus klausimus bei teiginius sąžiningai ir savarankiškai.

Statistiné analizè. Statistinè tyrimo duomenu analizė atlikta naudojant programu paketa SPSS for Windows. Aprašomosios statistikos metodais apskaičiuotos įvairių rodiklių skaitinès charakteristikos (vidurkiai, standartinès paklaidos ir kt.). Vertinant apklausos duomenis buvo skaičiuojamas tiek vidutinis teiginiu balas, tiek procentinis atsakymu $i$ klausimus duomenu pasiskirstymas. Hipotezès apie gautų duomenų vidurkių lygybę tikrinamos panaudojant parametrinius metodus. Tais atvejais, kai duomenys buvo išreikšti balais, hipotezèms tikrinti taikytas Stjudento $t$ testas, o vidurkiu skirtumas tarp procentiniu duomenu tikslinamas naudojant Pirsono chi kvadrato kriterijų. Rezultatai laikyti statistiškai reikšmingais, jei paklaidos tikimybės reikšmė $\mathrm{p}<0,05$, esant $95 \%$ patikimumui.

\section{REZULTATAI}

Motyvacijos mokytis užsienio kalbų tyrimas atskleidè, kad labiausiai šias studijas, studentų nuomone, lemia noras būti išsilavinusiu žmogumi, galimybè lengviau issidarbinti bei mokymosi kaip savo pareigos siekiant karjeros suvokimas (1 lent.).

Kaip mažiau reikšmingus motyvus studentai nurodè norą tęsti studijas, būti vertinamais jiems artimų žmonių, draugų, pažistamų.

Motyvaciją mokytis užsienio kalbų įvertinus balais, gauti kai kurie statistiškai reikšmingi skirtumai pagal lytį ir fakultetus. Sporto biomedicinos fakulteto studentų vidutinis motyvacijos mokytis užsienio kalbos balas buvo aukštesnis nei studijuojančiujų Sporto technologijų ir turizmo fakultete $(4,19 \pm 0,07$ ir 4,01 $\pm 0,04 ; p<0,05)$, tačiau kiek mažiau skyrèsi nuo studijuojančiuju Sporto edukologijos fakultete $(4,19 \pm 0,07$ ir $4,05 \pm 0,05 ; p>0,05)$. Merginos, lyginant jas su vaikinais, labiau motyvuotos studijuoti užsienio kalbas $(4,23 \pm 0,03$ ir 3,88 $\pm 0,04 ; p<0,001)$.

Pagal motyvacijos mokytis užsienio kalbu duomenis tiriamieji buvo suskirstyti $\mathfrak{i}$ dvi grupes: žemos ir aukštos mokymosi motyvacijos. Skirstyta atsižvelgiant i bendrą mokymosi motyvacijos vidurki - tie, kurių motyvacijos mokytis užsienio kalbų îvertis aukštesnis nei bendras vidutinis balas, buvo priskirti aukštos mokymosi motyvacijos grupei, o tie, kurių ivertis žemesnis nei bendras vidutinis balas, - prie žemesnès mokymosi motyvacijos grupès. I aukštos motyvacijos grupę pateko $54,4 \%$, o į žemos - 45,6\% apklaustujų. Čia taip pat nustatytas reikšmingas skirtumas pagal lytį: daugiau merginu nei vaikinu pateko į aukštesnès motyvacijos grupe $(70,5$ ir $39,1 \% ; p<0,001)$.

Dauguma tyrimo dalyvių studijas akademijoje rinkosi dèl noro turèti aukštojo mokslo diplomą $(80,5 \%)$. Kiek mažiau jų akademiją rinkosi dèl sportavimo motyvu $(56,3 \%)$ ir dèl didesnès, jų manymu, galimybès gauti geresni darbą $(53,9 \%)$. Visais atvejais išryškejjo skirtumas pagal lytį. Antai merginos dažniau nei vaikinai studijas akademijoje rinkosi dèl noro turèti aukštojo mokslo diplomą $(86,4$ ir $74,5 \% ; p<0,05)$ ir galimybès gauti geresni darbą $(65,0$ ir $42,7 \%$; $\mathrm{p}<0,001)$, o vaikinai dažniau nurode, kad jiems patinka sportas $(70,9$ ir $41,7 \%$; $<<0,001)$. Kur kas mažiau merginų ir vaikinu (atitinkamai 13,6 ir 5,5\%; $\mathrm{p}<0,05)$ studijas akademijoje rinkosi dèl to, kad jiems patinka mokytis.

Lyginant stojimo i akademiją motyvus su motyvacija mokytis užsienio kalbų pastebèta, kad noras turèti aukštojo mokslo diplomą būdingesnis aukštos mokymosi motyvacijos studentams $(85,5$ ir $74,4 \% ; p<0,05)$. Jie taip pat išsiskyre tokiais stojimo i akademiją motyvais kaip noru turèti galimybę gauti geresni darbą $(62,4$ ir $42,7 \%$; $\mathrm{p}<0,01)$, būti studentu $(28,2$ ir $14,6 \% ; \mathrm{p}<0,01)$ ir kad jiems patinka mokytis $(12,8$ ir $5,2 \%$; 


\begin{tabular}{|c|c|c|c|c|c|c|}
\hline Motyvas Ivertis & $\begin{array}{l}\text { Labai } \\
\text { svarbu }\end{array}$ & Svarbu & $\begin{array}{l}\text { Vid. } \\
\text { svarbu }\end{array}$ & Nesvarbu & $\begin{array}{c}\text { Visai } \\
\text { nesvarbu }\end{array}$ & \multirow{11}{*}{$\begin{array}{l}1 \text { lentelè. Motyvų, le- } \\
\text { miančių LKKA stu- } \\
\text { dentų užsienio kalbų } \\
\text { mokymąsi, procentinis } \\
\text { skirstinys }\end{array}$} \\
\hline Matau geras uždarbio galimybes & 35,8 & 39,1 & 21,9 & 1,9 & 1,3 & \\
\hline $\begin{array}{l}\text { Suprantu mokymąsi kaip savo pareigą } \\
\text { siekiant karjeros }\end{array}$ & 46,5 & 36,7 & 14,9 & 1,4 & 0,5 & \\
\hline Noriu būti vertinamas man artimų žmonių & 16,7 & 34,9 & 31,6 & 14,4 & 2,4 & \\
\hline Noriu tapti kompetentingu specialistu & 48,4 & 34,9 & 13,5 & 2,8 & 0,4 & \\
\hline Lengviau isidarbinti & 54,4 & 35,3 & 9,4 & 0,9 & 0 & \\
\hline Noriu tęsti studijas & 29,3 & 44,2 & 21,4 & 4,8 & 0,5 & \\
\hline Noriu būti vertinamas draugų, pažistamų & 8,8 & 25,6 & 43,3 & 19,0 & 3,3 & \\
\hline Noriu gauti gerus pažymius & 37,7 & 38,1 & 19,5 & 2,8 & 1,9 & \\
\hline Noriu būti išsilavinusiu žmogumi & 67,0 & 28,4 & 4,6 & 0 & 0 & \\
\hline Patinka tobulèti, sužinoti ką nors naujo & 40,5 & 40,8 & 16,3 & 1,9 & 0,5 & \\
\hline
\end{tabular}

$\mathrm{p}<0,06$ ), tačiau pastarieji motyvai ir vieniems, ir kitiems buvo mažiau aktualūs.

Sugretinę motyvacijos mokytis užsienio kalbų duomenis su kitais tyrimo kintamaisiais pastebèjome, kad aukštesnès motyvacijos studentai dažniau nei žemos nurodè aktyvaus dalyvavimo užsièmimuose svarbą $(59,0$ ir $44,9 \% ; \mathrm{p}<0,05)$, labiau akcentavo gebejimą reikšti mintis raštu ir žodžiu $(83,8$ ir $70,4 \% ; p<0,01)$, jas apibendrinti $(35,0$ ir $22,4 \% ; p<0,05)$. Išreikšdami požiūri i mokymosi būdus, galinčius padèti išmokti užsienio kalbą, aukštesnès motyvacijos studentai dažniau nurodė literatūros pagal specialybę skaitymo igūdžių tobulinimo svarbą $(32,5 \mathrm{ir}$ $17,5 \% ; \mathrm{p}<0,01)$, specialybės žodyno turtinima $(64,1$ ir $43,9 \% ; p<0,01)$. Tačiau ir vieni, ir kiti buvo tos nuomonès, kad efektyviausias būdas, padedantis išmokti užsienio kalbų, - šnekamosios kalbos igūdžiu tobulinimas diskusijų metu $(81,2$ ir $71,4 \%)$. Panaši dalis tiriamujų $(82,9$ ir $74,5 \%)$ isitikinusi, kad būsimajame darbe svarbiausia bus suprasti ir susikalbèti su užsienio specialistais, todèl, jų nuomone, ypač svarbu ivvaldyti šnekamają kalbą. Daugiau taip manančių buvo tarp aukštesnès mokymosi motyvacijos studentu ( 83,8 ir $69,4 \%$; $\mathrm{p}<0,01)$. Kur kas mažiau motyvacijos grupėse buvo studentų (po 26,5\%), išskiriančių literatūros pagal specialybę skaitymo svarbą.

Lyginant motyvacijos mokytis užsienio kalbu duomenis su požiūrio ị sportavimą duomenimis, pastebèta tendencija: daugiau studentų, lankančių sporto šakos treniruotes ir siekiančių rezultatų, pateko i žemesnès motyvacijos grupę, palyginus su tais, kurie nesiekia sportinių rezultatų arba lanko tik privalomus užsièmimus pagal studijų programą $(53,2$ ir $43,1 \%)$. Daugiau motyvacijos sąsajų, lyginant ją su kitais tyrimo kintamaisiais, nepastebèta.

Savigarbos tyrimas atskleide, kad kiek daugiau tirtų studentų pateko i mažos savigarbos grupę (51,2\%). Ryškesnis skirtumas nustatytas pagal lyti. Daugiau vaikinų nei merginų pateko į didelès savigarbos grupę $(55,5$ ir $41,9 \% ; p<0,05)$. Šias grupes lygindami pagal kitus tiriamiesiems užduotus klausimus pastebejome, kad jos skiriasi aiškinantis asmens savybes, galinčias daryti itaką nepažangiam mokymuisi. Antai dažniau nepasitikejjimą savo jègomis jaučia mažos savigarbos studentai $(37,2$ ir $9,5 \% ; p<0,05)$. Jie taip pat dažniau nerimauja dèl nepakankamo žinių lygio $(32,6$ ir $9,5 \% ; p<0,05)$, tačiau rečiau nei didesnès savigarbos jų bendramoksliai nurodo, kad per mažai laiko skiria savarankiškoms užduotims atlikti $(44,2$ ir $71,4 \% ; \mathrm{p}<0,05)$.

Déstytojų ir studentų gerų tarpusavio santykių svarbą vienodai vertino ir didelès, ir mažos savigarbos studentai. Skirtumas tik tas, kad klysti rečiau bijo mažos savigarbos studentai $(64,6$ ir $47,6 \% ; p<0,01)$. Nerasta skirtumo tarp savigarbos grupiu pagal pareikštą nuomonę apie veiksnius, galinčius daryti itaką užsienio kalbų mokymuisi. Ir vieni, ir kiti tarp pagrindiniu veiksnių nurodo malonią mokymosi aplinką (53,3\% didelès savigarbos studentų ir 44,5\% mažos savigarbos), mokymosi priemoniu gausa (44,8 ir $39,1 \%)$, aktyvumą užsièmimų metu (50,5 ir 54,5\%). Nesiskiria nuomonès ir pagal jų išskirtas asmenines savybes kaip svarbias užsienio kalbų mokymuisi. Ir didelès, ir mažos savigarbos studentai beveik vienodai nurodo šias savybes: ryžtingumą (atitinkamai 53,3 ir 60,9\%), kantrybę $(65,7$ ir $64,5 \%)$, pareigingumą $(49,5$ ir $51,8 \%)$. 


\begin{tabular}{|c|c|c|c|c|}
\hline \multirow{3}{*}{$\begin{array}{l}2 \text { lentelè. Motyvacijos mo- } \\
\text { kytis užsienio kalbu pro- } \\
\text { centinis skirstinys pagal } \\
\text { fakultetus }\end{array}$} & $\begin{array}{ll}\text { Motyvacijos lygmuo } & \text { Fakultetai } \\
\end{array}$ & $\begin{array}{l}\text { Sporto } \\
\text { biomedicinos }\end{array}$ & $\begin{array}{l}\text { Sporto } \\
\text { edukologijos }\end{array}$ & $\begin{array}{l}\text { Sporto } \\
\text { technologijuc }\end{array}$ \\
\hline & Aukšta motyvacija & 75,6 & $51,8^{*}$ & $48,3 * *$ \\
\hline & Žema motyvacija & 24,4 & 48,2 & 51,7 \\
\hline
\end{tabular}

Pastaba. * - skirtumas tarp Sporto biomedicinos ir Sporto edukologijos fakultetų $(\mathrm{p}<0,02)$;

** — skirtumas tarp Sporto biomedicinos bei Sporto technologijų ir turizmo fakultetų $(\mathrm{p}<0,002)$.

\begin{tabular}{|l|l|l|l|l|}
$\begin{array}{l}3 \text { lentelè. Motyvacijos } \\
\text { mokytis užsienio kalbų } \\
\text { priklausomybė nuo savi- } \\
\text { garbos lygmens (\%) }\end{array}$ & Savigarbos lygmuo & Aukštas & Žemas & Skirtumo patikimumas $\mathrm{p}$ \\
& Motyvacijos lygmuo & 61,0 & 48,2 & $\mathrm{p}<0,01$ \\
\cline { 2 - 5 } & Aukšta motyvacija & 39,0 & 51,8 & $\mathrm{p}<0,05$ \\
\cline { 2 - 4 } & Žema motyvacija & & \\
\hline
\end{tabular}

\begin{tabular}{|c|c|c|c|}
\hline \multirow{3}{*}{$\begin{array}{l}4 \text { lentelè. Studentų nuo- } \\
\text { monès apie gerus dėsty- } \\
\text { tojų ir studentų tarpusa- } \\
\text { vio santykius raiška mo- } \\
\text { tyvacijos mokytis užsienio } \\
\text { kalbų grupèse (\%) }\end{array}$} & Tarpusavio santykių bruožai & $\begin{array}{c}\text { Aukštos } \\
\text { motyvacijos }\end{array}$ & $\begin{array}{c}\text { Žemos } \\
\text { motyvacijos }\end{array}$ \\
\hline & Didesnė tikimybė, kad žinios bus įvertintos geresniu pažymiu & 12,6 & 19,8 \\
\hline & Geri tarpusavio santykiai ikvepia nora geriau mokytis & 82,9 & $65,9 *$ \\
\hline \multirow[b]{2}{*}{ Pastaba. ${ }^{*}-\mathrm{p}<0,05$} & Galima drąsiau klausti to, kas neaišku & 83,8 & 74,7 \\
\hline & Nebaisu dažniau klysti & 55,9 & 56,0 \\
\hline
\end{tabular}

Savigarbos grupių tiriamuju požiūris labiau skiriasi vertinant asmenines pastangas mokantis užsienio kalbų. Jų svarbą daugiau akcentavo didelès savigarbos studentai $(76,2$ ir $63,6 \%$; $\mathrm{p}<0,05)$. Jie taip pat labiau išskyrè šnekamosios kalbos igūdžiu svarbą būsimajame darbe $(82,9$ ir $71,8 \% ; p<0,05)$, o mažesnès savigarbos studentai dažniau akcentavo mokejjimą bendrauti buitine kalba $(46,4$ ir $31,4 \%$; p < 0,05).

Kaip ir tikètasi, daugiau didesnès savigarbos studentų lankè sporto šakos treniruotes ir siekè rezultatu $(56,0$ ir $39,8 \% ; \mathrm{p}<0,05)$. Skirtumu pagal kitus tyrimo kintamuosius (tèvų socialinę padèti, jų išsilavinimą, savo materialinès padèties suvokimą, darbą studijų metu, šeimyninę padèti), kaip ir mokymosi motyvacijos atžvilgiu, nerasta.

Atliekant tyrimą mums buvo svarbiau sugretinti tuos duomenis, kurie leistu patikrinti keltas prielaidas, t. y. motyvacijos mokytis užsienio kalbų priklausomybę nuo savigarbos, santykių su destytojais ir pasirinktos studiju krypties. Tyrimo duomenu apie mokymosi motyvacijos priklausomybę nuo studiju krypties sugretinimas (2 lent.) parodè, kad labiau motyvuoti mokytis užsienio kalbų yra Sporto biomedicinos fakulteto studentai, tarp kurių didesnis procentas pateko i aukštesnès motyvacijos grupę. Mažai skyrèsi motyvacijos raiška tarp Sporto edukologijos bei
Sporto technologijų ir turizmo fakulteto studentų. Beveik vienodas ju procentas pateko ir i aukštos, ir į žemos motyvacijos grupes.

Sugretinus mokymosi motyvacijos ir savigarbos duomenis (3 lent.) pastebeta, kad daugiau didelès savigarbos studentų pateko i aukštos motyvacijos mokytis užsienio kalbų grupę ir mažiau - i žemos motyvacijos grupę. Vadinasi, didesnès savigarbos studentai labiau motyvuoti mokytis užsienio kalbų.

Kai kurie tirtų studentų motyvacijos mokytis užsienio kalbų skirtumai nustatyti analizuojant santykius su dèstytojais (4 lent.). Lentelès duomenys rodo, kad labiau motyvuoti mokytis užsienio kalbų studentai dažniau pabrèžia gerų tarpusavio santykių su dèstytojais svarbą siekiant geresnių mokymosi rezultatų. Jie taip pat dažniau linkę klausti to, kas neaišku, ir rečiau issitikinę, kad žinios bus iqvertintos geresniu pažymiu.

\section{REZULTATU APTARIMAS}

Tyrimo, kurio metu buvo siekta atskleisti LKKA studentų motyvacijos mokytis užsienio kalbų raišką bei nustatyti jos sąsajas su studijų kryptimi ir psichosocialinès sveikatos rodikliais, rezultatai patvirtino pirmają mūsų keltą prielaidą dèl motyvacijos ir psichosocialinès sveikatos sassajos. Tai leidžia manyti, kad gera psichosocialinè 
sveikata gali būti veiksnys, padedantis studentams susidaryti palankesni požiūrị i užsienio kalbu mokymąsi. Gauti duomenys pakartoja kitų tyrimų rezultatus, atskleidusius moksleivių mokymosi motyvacijos ir psichosocialinès sveikatos duomenu sąsają (Leiputè, Kardelis, 2002).

Labiausiai išryškejjo savigarbos ir motyvacijos ryšys, leidžiantis teigti, kad dauguma mokymosi problemų greičiausiai yra susiję ne su intelektu, o su asmenybe. Tai, kad sėkminga mokymosi veikla labiau priklauso nuo motyvacijos ir asmenybès savybių negu nuo intelekto, patvirtina ir kiti tyrèjai (Дружинин, 1995; Реан, Коломинский, 1999). Viena vertus, tai gali būti susiję su asmenybès savybèmis (motyvacija mokytis, savęs vertinimu), antra vertus, su jų visuma - asmenybės darna arba psichosocialine sveikata. Nurodoma, kad įvairūs motyvacijos mokytis, savigarbos, socialinès integracijos ir kt. sutrikimai yra susiję su vidinès darnos stoka (Butkienė, Kepalaite, 1996). Taip pat nustatyta moksleivių motyvacijos mokytis sąsaja su psichologine savijauta, mokyklos baime. Tie mokiniai, kurių vidiné motyvacija mokytis yra stipri, geriau mokosi (Мильман, 1987) ir geriau jaučiasi mokykloje (Pileckaitè-Markovienè, 2001). Galima daryti prielaidą, kad analogiški motyvacijos mokytis ir psichologiniu veiksniu sąsajų dèsningumai būdingi ir studentams, nes, pavyzdžiui, jų saugumo jausmą bei geresnę psichosocialinę sveikatą rodo tai, kad studentai, turintys aukštesnę motyvaciją mokytis užsienio kalbų, dažniau pabrèžia gerų tarpusavio santykių su déstytojais svarbą siekiant mokymosi rezultatu ir dažniau linkę klausti to, kas neaišku. Tačiau geresni santykiai su dèstytojais nèra siejami su tikimybe gauti geresni pažymi, kuris studentams yra svarbus rodiklis, ịvertinantis jų užsienio kalbos mokèjimą. Kita vertus, aukštesnis pažangumo balas gali padidinti pasitikejimą savo jègomis. Idomu pastebèti, kad kai kurie autoriai tai vertina kaip tam tikrus mainus už darbą, nes besimokantiems, kaip ir visiems kitiems, galima sužadinti motyvaciją daryti tam tikrus dalykus dèl išorinio paskatinimo (Arends, 1994), tačiau tai, anot autoriaus, silpnina besimokančiujų vidinę motyvaciją. Kitų autorių (Gage, Berliner, 1994) nuomone, tai nèra blogai, nes dažniausiai tai daro teigiama poveiki (sumaniai naudojant išorini paskatinima), ir ypač tada, kai besimokantysis jau turi stiprią vidinę motyvaciją. Tuomet išoriniai pastiprinimai motyvacijos nedidina. Pastaraja nuomonę patvirtina ir mūsų tyrimo duomenys.
Negalima neivertinti ir tokio ne mažiau svarbaus veiksnio, galinčio daryti itaką motyvacijai mokytis užsienio kalbų, kaip studentų akademinis identitetas, kuris yra susijęs su asmens saviverte, savivoka akademineje veikloje bei savijauta studijų aplinkoje. Atliktas tyrimas parodè glaudžia akademijos studentų studijų pasiekimų ir jų akademinio identiteto sąsają, t. y. studentai, kurių studijų pasiekimai yra didesni, išsiskiria ir aukštesniais akademinio identiteto rodikliais. Idomu ir tai, kad aukštesnio akademinio identiteto studentai akademijoje jaučiasi geriau, taip pat ją vertina palankiau (Karanauskienè, Kardelis, 2005). Galima manyti, kad ir jų savigarba yra didesnè, kartu geresnè ir psichosocialinè sveikata. Vadinasi, tinkamos mokymosi aplinkos kūrimas, geri desstytojų ir studentu tarpusavio santykiai turètų būti svarūs argumentai, galintys paskatinti studentų motyvaciją mokytis užsienio kalbų. I tai orientuoti ir kitų tyrèjų išsakyti teiginiai apie psichologinių sąlygų (desstytojo ir studento sąveikos) svarbą kuriant studento mokymosi edukacinę aplinką (Gardner, 1995; Lipinskienè, 2002). Savo ruožtu susiformavęs teigiamas požiūris i mokymąsi gali sustiprinti asmens savigarbą (Чаркова, 2004).

Pasitvirtino ir antroji prielaida, kad motyvacija mokytis užsienio kalbų gali prognozuoti studijų kryptis. Tyrimo duomenimis, labiau motyvuoti mokytis užsienio kalbų buvo Sporto biomedicinos fakulteto studentai. Tai gali paaiškinti jų silpnesnè identifikacija su sportine veikla. Pastebèta, kad sportuojančių studentų akademinis identitetas, susijęs su motyvacija mokytis, yra silpnesnis (Karanauskienè, Kardelis, 2005). Taip pat galima galvoti, kad mokymosi pasiekimai jiems kelia didesni pasitenkinimą, o jų ateities planai skatina labiau stengtis mokantis užsienio kalbų. Nereikètu aiškinti motyvacijos mokytis užsienio kalbų skirtumų, išryškejjusių tarp fakultetų, tik identifikacijos su sportine veikla ypatumais. Tai gali būti siejama ir su profesijos visuomeneje prestižu, ir su stojimo į akademiją motyvais, kurie parode, kad žemesnès motyvacijos mokytis užsienio kalbų studentai rečiau nurodè tokius stojimo motyvus, kaip noras būti studentu, patinka mokytis. Jie taip pat rečiau studijų svarbą sieja su galimybe gauti darbą, noru tapti labiau išprususiais. Norint visapusiškai išanalizuoti ši klausimą, reikètų papildomų duomenų, galinčių išsamiau paaiškinti motyvacijos mokytis užsienio kalbų skirtumų priklausomybę nuo studijų krypties. 


\section{IŠVADOS}

1. Motyvacijos mokytis užsienio kalbų raiškos tyrimas atskleide, kad labiausiai studentus mokytis užsienio kalbų skatina vidiniai motyvai, susiję su pareigos siekiant karjeros suvokimu ir noru būti išsilavinusiu žmogumi. Kur kas mažiau užsienio kalbų studijas motyvuoja tokie išoriniai veiksniai kaip aplinkinių žmonių (artimujų, draugų, pažistamų) vertinimai.

2. Nustatyti motyvacijos mokytis užsienio kalbu skirtumai pagal šiuos tyrimo kintamuosius:

- stojimo į akademiją motyvus (aukštesnès motyvacijos studentai išskyrè norą turèti aukštojo mokslo diplomą ir galimybę gauti geresni darba);

- asmens pastangas mokantis užsienio kalbų bei asmenines savybes (aukštesnès motyvacijos studentai labiau akcentavo aktyvaus dalyvavimo užsièmimuose svarbą ir išskyrè tokias asmenybès savybes kaip darbštumas, ryžtingu- mas, gebejjimas reikšti mintis raštu ir žodžiu, jas apibendrinti);

- mokymosi būdus (aukštesnès motyvacijos studentai dažniau nurodo specialybès literatūros skaitymo igūdžių tobulinimą, specialybès žodyno turtinimą, šnekamosios kalbos igūdžių svarbą komunikacinių gebejimų lavinimui);

- požiūrị i sportavimą (studentų, lankančių sporto treniruotes ir siekiančių rezultatų, motyvacija mokytis užsienio kalbų buvo žemesnè nei tu, kurie nesiekia sportinių rezultatų arba lanko tik privalomus užsièmimus pagal studijų programą);

- lyti (merginos, lyginant su vaikinais, išsiskyrè aukštesne motyvacija mokytis užsienio kalbų).

3. Egzistuoja sąsaja tarp motyvacijos mokytis užsienio kalbų, savigarbos, santykių su dèstytojais ir studiju krypties. Studentai, kurių motyvacija mokytis užsienio kalbų yra aukštesnè, yra didesnès savigarbos, labiau pabréžia tarpusavio santykių su dèstytojais svarbą, yra pasirinkę studijas Sporto biomedicinos fakultete.

\section{LITERATŪRA}

Arends, R. (1994). Mokomès mokyti. Vilnius: Margi raštai.

Balžakienè, J. (1998). LKKI studentu požiūris į užsienio kalbų mokymąsi. Pedagogika, 37, 88-96.

Brunevičiūtè, R. (2003). Mokymo(-si) strategijos pasirinkimas profesinès kalbos studijoms. Kalbu studijos, 4, $1-5$.

Butkienè, G., Kepalaite, A. (1996). Mokymasis ir asmenybès brendimas. Vilnius: Margi raštai.

Dereškevičius, P. (2000). Mokyklos nelankymo priežastys. Vilnius: Žuvėdra.

Fisher, J., Corcoran, K. (1987). Measures for Clinical Practice. A Source Book, Vol. 1, 518-520.

Gage, N. L., Berliner, D. C. (1994). Pedagogine psichologija. Vilnius: Alma littera.

Gardner, R. C. (1995). Social Psychology and Second Language Learning: The Role of Attitudes and Motivation. London: Edward Arnold.

Karanauskienè, D., Kardelis, K. (2005). The relationship between student's academic identity and academic achievements. Socialiniai mokslai, 1 (47), 62-70.

Kohohen, V. (1994). Užsienio kalbu mokymasis kaip besimokančiojo ugdymas: kaip palengvinti savarankišką kalbų mokymąsi. Śvietimo naujoves, 1, 34-35.

Leipute, O., Kardelis, K. (2002). Vaiku globos namų ugdytiniu psichosocialinès sveikatos ir mokymosi motyvacijos duomenų sąsaja. Ugdymas. Küno kultūra. Sportas, 1 (42), 15-21.
Lipinskiené, D. (2002). Edukaciné studenta igalinanti studijuoti aplinka: daktaro disertacijos santrauka. Kaunas: KTU.

Petrauskaite, R. (1995). Profesijos pasirinkimo racionalumo posovietineje Lietuvoje psichopedagoginiai ypatumai: daktaro disertacijos santrauka. Klaipeda: KU.

Pileckaitė-Markovienė, M. (2001). Pradinių klasių moksleiviu mokymosi motyvacija, psichologinè savijauta ir mokyklinis nerimastingumas. Psichologija, 23, 23-49.

Rebecca, J. D., Lorraine, G. D. (1998). Access to Health. Oregon State University: University of Oregon.

Šliogerienè, J. (2004). Mokymosi motyvacija specialybinès anglu kalbos mokymo kontekste. Tiltai, 19, 147.

Vaznonienè, R., Danilevičienè, L. (2004). Studentų motyvacija studijuoti užsienio kalbas aukštojoje mokykloje. Ugdymas. Küno kultūra. Sportas, 1 (51), $68-75$.

Дружинин, В. Н. (1995). Психология общих способностей. Москва: Лантерна: Вита.

Мильман, В. Э. (1987). Внутренняя и внешняя мотивация учебной деятельности. Вопросы психологии, 5, 129-138.

Реан, А. А., Коломинский, Я. Л. (1999). Социиальная педагогическая психология. Санкт-Петербург: Питер.

Чаркова, М. Н. (2004). Возрастные особенности развития свойств внимания под влиянием мотивационного фактора (результаты исследования). Мир психологии, $1,231-241$. 


\title{
FACTORS DETERMINING STUDENTS' FOREIGN LANGUAGE LEARNING MOTIVATION AT LITHUANIAN ACADEMY OF PHYSICAL EDUCATION
}

\author{
Aurelija Kuzmienė, Irena Čikotienė, Kęstutis Kardelis \\ Lithuanian Academy of Physical Education, Kaunas, Lithuania
}

\begin{abstract}
The paper deals with the research, the aim of which is to reveal the foreign language learning motivation and to evaluate the factors, which determine their learning. It has been hypothesized that students' foreign language learning motivation is closely related to their psycho-social health and also it depends on a study area. 225 first and second year students at three faculties of the Lithuanian Academy of Physical Education have been investigated by filling in the questionnaires. Some psycho-social indicators as self-esteem, inter-relations with teachers have been chosen as other variables of the research. The results showed that the foreign language learning motivation is mostly based on the wish to be an educated person (67.4\%). Possibility for easier employment (54.4\%) motivates foreign language learning less as well as the wish to be more competent $(48.4 \%)$. The paper presents some results and describes some significant findings on an existing coherence between students' foreign language learning motivation and their self-esteem, as well as inter-relations with teachers and study area. Students with higher motivation for learning are characterized as having higher self-esteem and they emphasize the importance of inter-relations with teachers. These students have chosen studies at the Faculty of Sports Biomedicine.
\end{abstract}

Keywords: students' motivation in foreign language learning, psycho-social health, study area.

Gauta $2005 \mathrm{~m}$. rugsèjo $20 \mathrm{~d}$.

Received on September 20, 2005

Priimta $2005 \mathrm{~m}$. gruodžio $28 \mathrm{~d}$.

Accepted on December 28, 2005

\author{
Aurelija Kuzmienè \\ Irena Čikotienè \\ Lietuvos kūno kultūros akademija \\ (Lithuanian Academy of Physical Education) \\ Sporto g. 6, LT-44221 Kaunas \\ Lietuva (Lithuania) \\ Tel. +370 37 302626; +37037302672 \\ E-mail a.kuzmiene@lkka.lt \\ E-mail i.cikotiene@lkka.lt
}

